\title{
Use of micropropagation in the vegetative rescue of adult trees of Cedrela odorata L.
}

\author{
Cezário Ferreira dos Santos Junior ${ }^{1 *} \oplus$, Murilo Dalla Costa ${ }^{2} \oplus$, \\ Tássio Dresch Rech ${ }^{2} \odot$, Pedro Boff ${ }^{2} \oplus$, Mari Inês Carissimi Boff ${ }^{1} \oplus$ \\ ${ }^{1}$ Universidade do Estado de Santa Catarina, Lages, SC, Brasil. E-mail: agrosantos01@gmail.com; mari.boff@udesc.br \\ 2Empresa de Pesquisa Agropecuária e Extensão Rural de Santa Catarina, SC,Brasil. E-mail: murilodc@epagri.sc.gov.br; tassior@epagri.sc.gov.br; boff.pedro@yahoo.com.br
}

ABSTRACT: The objective of this work was the vegetative rescue of Cedrela odorata $L$. adult trees from forest areas by micropropagation using shoot regeneration from axillary buds in vitro. Nodal segments $(0.5$ and $1.0 \mathrm{~cm})$ of shoots formed from cuttings taken from canopy sprouts were used. The explants were successfully established in vitro on MS medium supplemented with $2.22 \mu \mathrm{M}$ BAP, $0.49 \mu \mathrm{M}$ AIB, $0.28 \mu \mathrm{M}$ GA3 and PPM $(0$ and $8.6 \mu \mathrm{M})$. Shoot multiplication on MS with combinations of GA3 $(0.28$ and $1.12 \mu \mathrm{M})$ and $\operatorname{BAP}(2.2,3.3,4.4,6.6$, and $8.8 \mu \mathrm{M})$ and shoot rooting on medium with $4.9 \mu \mathrm{M}$ AIB, $5.7 \mu \mathrm{M}$ AIA or 5.37 $\mu \mathrm{M}$ ANA were evaluated. The MS medium supplemented with $0.28 \mu \mathrm{M} \mathrm{GA3}$ and $8.8 \mu \mathrm{M}$ BAP generated 4.16 shoots per explant. The best rooting induction was observed on medium containing $4.9 \mu \mathrm{M} \mathrm{IBA}$, resulting in $60 \%$ of shoot rooting. The plantlets rooted were acclimatized and showed normal development with $97 \%$ survival rate. The use of canopy sprouts as explants is feasible in the rescue of $C$. odorata and the combination of BAP and GA3 favors in vitro multiplication.

Key words: Meliaceae; plant growth regulators; tissue culture

\section{Uso da micropropagação no resgate vegetativo de árvores adultas de Cedrela odorata $\mathrm{L}$.}

RESUMO: $O$ objetivo deste trabalho foi o resgate vegetativo de árvores adultas de Cedrela odorata $\mathrm{L}$. de áreas florestais por micropropagação utilizando regeneração de brotos de gemas axilares in vitro. Foram utilizados segmentos nodais $(0,5$ e $1,0 \mathrm{~cm})$ de brotações formadas de estaca retiradas de ramos da copa. Os explantes foram estabelecidos com sucesso in vitro em meio MS suplementado com 2,22 $\mu \mathrm{M}$ BAP; 0,49 $\mu \mathrm{M}$ AIB; $0,28 \mu \mathrm{M}$ GA3 e PPM ${ }^{\mathrm{TM}}(0$ e 8,6 $\mu \mathrm{M})$. Avaliados a multiplicação de brotos em MS com combinações de GA3 (0,28 e 1,12 $\mu \mathrm{M})$ e BAP $(2,2 ; 3,3 ; 4,4 ; 6,6$ e 8,8 $\mu \mathrm{M})$ e o enraizamento de brotos em meio com 4,9 $\mu \mathrm{M}$ AIB; $5,7 \mu \mathrm{M}$ AIA e 5,37 $\mu \mathrm{M}$ ANA. 0 meio MS suplementado com 0,28 $\mu \mathrm{M}$ GA3 e 8,8 $\mu \mathrm{M}$ de BAP gerou 4,16 brotações por explante. A melhor indução de enraizamento foi observada em meio contendo $4,9 \mu \mathrm{M}$ de IBA, resultando em $60 \%$ de explantes enraizados. As plântulas enraizadas foram aclimatadas e apresentaram desenvolvimento normal com taxa de sobrevivência de $97 \%$. O uso de brotos de dossel como explantes é viável no resgate de C. odorata e a combinação de BAP e GA3 favorece a multiplicação in vitro.

Palavras-chave: Meliaceae; reguladores de crescimento de plantas; cultura de tecidos

\footnotetext{
* Cezário Ferreira dos Santos Junior - E-mail: agrosantos01@gmail.com (Corresponding author)

Associate Editor: Giuseppina Pace Pereira Lima
} 


\section{Introduction}

Cedrela odorata L. Meliaceae is distributed in subtropical, tropical, and seasonal forests extending from Mexico to Argentina (Cervi et al., 2008). Due to the economic importance of the wood of $C$. odorata, the extractive exploitation, which added to the low regeneration capacity, has taken the species to the category of endangered (Brasil, 2014). Another limiting factor to the establishment of commercial $C$. odorata forests is the presence of the insect Hypsipyla grandella (Zeller, 1848) (Lepidoptera: Pyralidae) which damages the tree's growing points, compromising the upright development of the stem as well as the development and growth of young trees (Castro et al., 2018).

In general, the propagation of cedar plants is done through seeds (Oliveira et al., 2013). However, this form of propagation is dependent on seed viability that is influenced by the seasonality of fruit dispersal and the low quality of diversity of productive matrices (Lesher-Gordillo et al., 2018). The $C$. odorata species presents allogamous pollination with great genetic diversity among the remaining populations (Martins et al., 2008). Propagation by woody cuttings has been studied, but presents low rooting capacity (Peña-Ramírez et al., 2010). The rescue of forest species by vegetative propagation can be influenced by the ontogenetic age of the tissue, and various techniques are applied to rejuvenate and/or invigorate plants (Stuepp et al., 2018). According to Alvim et al. (2020), in forest species with low propagative rate by seeds, micropropagation enables in vitro conservation of invigorated material, mass multiplication and the selection of genetically superior matrices.

Among the main factors that limit the in vitro regeneration of some species is the explant source, definition of the appropriate culture medium and concentration of growth regulators (Bidabadi \& Jain, 2020). Micropropagation is carried out through the stages of establishment, selection of explants and disinfestation, multiplication, rooting, and acclimatization (Cançado et al., 2013). Other limitations in establishment are the high rate of contamination by unwanted microorganisms and the oxidation of explants, which is quite common in the micropropagation of forest species (Salles et al., 2017).

The micropropagation of $C$. odorata showed satisfactory results using explants from seedlings originated from the in vitro germination of seeds (Pérez et al., 2002; Valverde-Cerdas et al., 2008). The use of sprouts from $C$. odorata cuttings has enabled the rescue and rooting of explants (GarcíaGonzáles et al., 2011). The in vitro establishment of woody species explants is one of the main stages for the success of micropropagation, since it involves overcoming oxidation and fungal and bacterial contamination (Almeida et al., 2020). Moreover, the definition of adequate concentrations of growth regulators is determinant in the in vitro multiplication phase of $C$. odorata (Peña-Ramírez et al., 2010).

Thus, this research aimed to evaluate the vegetative rescue of adult trees of $C$. odorata $L$. by micropropagation using nodal segments from budded cuttings collected from crown branches.

\section{Materials and Methods}

\section{Induction of bud sprouts from cuttings and production of} explants

The research was conducted at the Laboratório de Biotecnologia of the Empresa de Pesquisa e Extensão Rural do Estado de Santa Catarina - EPAGRI, Lages, Santa Catarina, Brazil. Branches were taken from the crown of three matrix plants of $C$. odorata with 15-20 years of age and DBH of 10$17.8 \mathrm{~cm}$, located in an area of natural regeneration of Mixed Ombrophylous Forest ( $27^{\circ} 42^{\prime} 55.52^{\prime \prime} \mathrm{S}, 50^{\circ} 30^{\prime} 24.29^{\prime \prime} \mathrm{O}, 876 \mathrm{~m}$ altitude), municipality of São José do Cerrito, state of Santa Catarina, Brazil.

The species identification was carried out with the help of literature and confirmed by botanical experts. Exsiccata were deposited in the Herbário Lages of the Universidade do Estado de Santa Catarina (LUSC). The branches were fractioned into $15 \mathrm{~cm}$ cuttings, and kept in plastic trays containing carbonized rice husk, in a controlled environment at $24 \pm 2$ o $C$, relative humidity between $67-71 \%$ and $8 \mathrm{~h}$ photoperiod.

\section{Asepsis and sprout regeneration in vitro}

After 35 days the cuttings generated $7-10 \mathrm{~cm}$ long shoots, the shoots were removed and fractionated into explants of 0.5 and $1.0 \mathrm{~cm}$ nodal segments containing an axillary bud. The explants were disinfected with $70 \%$ ethanol for 30 seconds and $2 \% \mathrm{NaClO}$ plus Tween 20 for 30 minutes. They were then washed three times with sterile water. Next, the explants were established on MS medium (Murashige \& Skoog, 1962) with $2.22 \mu \mathrm{M}$ of 6-benzylaminopurine (BAP); $0.49 \mu \mathrm{M}$ of indolbutyric acid (AIB); $0.28 \mu \mathrm{M}$ gibberellic acid (GA3); and, 30 g L-1 of saccharose (García-Gonzáles et al., 2011; Mroginski \& Rey, 2012), whether or not supplemented with $8.6 \mu \mathrm{M}$ of $\mathrm{PPM}^{\circledR}$ (Plant Preservative Mixture; $0.135 \%$ of the 5-chloro-2-methyl-3(2H)-isothiazolone and $0.041 \%$ of the 2-methyl-3(2H)-isothiazolone) to evaluate the capacity to prevent microbial contamination (Peña-Ramírez et al., 2011). The media were gelled with $8 \mathrm{~g} \mathrm{~L}-1$ agar and the $\mathrm{pH}$ was adjusted to 5.8 before autoclaving at $121^{\circ} \mathrm{C}$ for 15 minutes. The cultures were maintained in a growth chamber at $25 \pm$ and $16 \mathrm{~h}$ photoperiod.

In vitro establishment treatments consisted of a combination of nodal segment size $(0.5$ or $1.0 \mathrm{~cm})$ and use of $\mathrm{PPM}^{\circledR}(0$ or $8.6 \mu \mathrm{M})$. The explants were kept in a completely randomized design with 25 repetitions per treatment, with one tube per plot, each tube containing one explant. After 30 days of in vitro establishment, survival rates (\%), regeneration percentage (shoots longer than $1 \mathrm{~mm}$ and presence of leaves), and oxidation rates (\%), fungal (\%) and bacterial (\%) contaminations were evaluated.

\section{In vitro multiplication}

In vitro regenerated shoots were subcultured and provided material for the in vitro multiplication experiment. 
In culture medium containing MS salts, combinations of five concentrations of $\operatorname{BAP}(2.2,3.3,4.4,6.6$, and $8.8 \mu \mathrm{M})$ and two concentrations of GA3 $(0.28$ and $1.12 \mu \mathrm{M})$. The culture media were supplemented with $30 \mathrm{~g} \mathrm{L-1}$ sucrose and gelled with 8 $\mathrm{g} \mathrm{L-1}$ agar, and the $\mathrm{pH}$ was adjusted to 5.8. The experiment was conducted in a randomized block design, factorial arrangement $2 \times 5$ (two doses of GA3 $\times$ five doses of BAP), with four repetitions of 16 explants per treatment. After 30 days of cultivation, the multiplication rate (\%), number of sprouts per explant, length of sprouts $(\mathrm{mm})$ and oxidation rate $(\%)$ were evaluated.

\section{Rooting and acclimatization}

The sprouts from the multiplication experiment were used for rooting using MS medium containing $30 \mathrm{~g} \mathrm{L-1}$ sucrose, $8 \mathrm{~g}$ L-1 agar and $\mathrm{pH} 5.8$ plus three auxin-type growth regulators: 4.9 $\mu \mathrm{M}$ of indolbutyric acid (AIB); $5.7 \mu \mathrm{M}$ indol-3-acetic acid (AIA); $5.37 \mu \mathrm{M}$ of naphthaleneacetic acid (ANA). Basal medium without a regulator was the control. The treatments were defined based on previous studies (Pérez et al., 2002; Valverde-Cerdas et al., 2008; García-Gonzáles et al., 2011). The experiment was in a randomized block design with four replications of 16 explants. After 30 days, rooting rate (\%), number of roots and root length $(\mathrm{cm})$ were evaluated.

Cultures with and without root formation were acclimated ex vitro in expanded polypropylene honeycombed trays

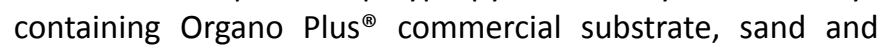
carbonized rice husk $(1: 1: 1, \mathrm{v} / \mathrm{v} / \mathrm{v})$, kept inside a $25 \mathrm{~L}$ polyethylene plastic tray and covered with transparent plastic film to form a humid chamber. The seedlings were irrigated with $250 \mathrm{~mL}$ of water every 3 days, using a sprayer. The trays

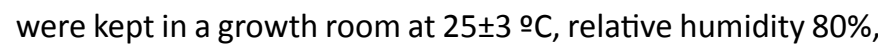
$16 \mathrm{~h}$ photoperiod. Rooted and unrooted seedlings constituted the treatments and were conducted in a completely randomized design with 40 replicates per treatment. After 30 days survival (\%) was evaluated.

\section{Statistical analysis}

For the in vitro multiplication and rooting experiments, the data were submitted to analysis of variance after verification of normality (Shapiro-Wilk) and homogeneity (Bartlett). In cases where the model assumptions were not met, Box-Cox transformation was performed. To evaluate the establishment and acclimatization experiments, generalized linear models (GLM) were used, since the variables presented a binomial probability distribution. Differences between the means of the treatments were compared by the Tukey test $(p \leq 0.05)$. All analyses were conducted in the R environment ( $R$ Core Team, 2018).

\section{Results and Discussion}

\section{Induction and regeneration of shoots in vitro}

Regeneration of shoots under in vitro conditions was possible using material rescued from $C$. odorata matrices. The treatments of explant size and $\mathrm{PPM}^{\circledR}$ concentration analyzed in the experiment showed no differences between the variables survival rates $(p=0.3508)$, fungal contamination $(p=0.0404)$ and oxidation $(p=0.0446)$ (Table 1$)$. The use of fungicides in asepsis of explants can be toxic, increasing the mortality of explants; García-Gonzáles et al. (2011) obtained in C. odorata disinfection of $100 \%$ of explants and establishment of $60 \%$ of explants from cuttings sprouts, using in asepsis Propiconazole CE 25 5\% for 3 minutes. The use of $\mathrm{PPM}^{\circledR}$ in the medium showed no effect in suppressing fungal contamination. However, Silveira et al. (2016) showed that using 0.4 and $0.8 \%$ PPM in WPM culture medium eliminated bacterial contamination and the $0.8 \%$ dose reduced fungal contamination to $2 \%$ in nodal segments obtained from $1-2$ year old seedlings of Calophyllum brasiliense.

Nodal segments with the size of $1.0 \mathrm{~cm}$ without addition of $\mathrm{PPM}^{\circledR}$ to the culture medium showed higher regeneration values than nodal segments of $0.5 \mathrm{~cm}(p=0.0012)$. According to Moura et al. (2012), larger nodal segments have relatively larger reserves of hormones and nutrients, providing better development of explants. However, Robert et al. (2020), in vegetative rescue of $C$. odorata using nodal segments obtained from grafted material observed higher regeneration compared to the use of cuttings buds under in vitro conditions.

\section{In vitro multiplication}

The multiplication rate $(p=0.0492)$, number of sprouts ( $p$ $<0.001)$ and explant length $(p=0.0016)$ were regulated by the interaction of BAP and GA3 concentrations in the culture medium (Table 2). The increase in the GA3 dose at the lower BAP doses promoted an increase in the number of shoots. At the dose of $0.28 \mu \mathrm{M} \mathrm{GA3}$ with the increase of the BAP dose there was a gradual increase in the number of shoots. The explants maintained on MS medium with $8.8 \mu \mathrm{M}$ BAP and $0.28 \mu \mathrm{M}$ GA3 showed 4.16 shoots per explant, differing from

Table 1. Survival (\%), regeneration (\%), fungal contamination (\%), and oxidation (\%) of 0.5 and $1.0 \mathrm{~cm}$ nodal segments of $C$. odorata in culture medium with or without addition of $\mathrm{PPM}^{\circledR}$.

\begin{tabular}{|c|c|c|c|c|c|}
\hline \multirow{2}{*}{$\begin{array}{c}\text { Nodal segment } \\
(\mathrm{cm})\end{array}$} & \multirow{2}{*}{$\begin{array}{l}\text { PPM } \\
\text { (uM) } \\
\end{array}$} & Survival & Regeneration & Fungus & Oxidation \\
\hline & & \multicolumn{4}{|c|}{$(\%)$} \\
\hline 1.0 & 0 & $80 \mathrm{~ns}$ & $65 a$ & $15 \mathrm{~ns}$ & $5^{\mathrm{ns}}$ \\
\hline 1.0 & 8.6 & 75 & $55 a b$ & 15 & 10 \\
\hline 0.5 & 8.6 & 60 & $30 \mathrm{~b}$ & 00 & 30 \\
\hline$p$-valor & & 0.3508 & 0.0012 & 0.0404 & 0.0446 \\
\hline
\end{tabular}

Different letter in column is different by Tukey test $(p<0.05)$. $n s$ : Treatments were not significantly different by Tukey test $(p \leq 0.05)$. Treatments: Nodal segment $(1.0 \mathrm{~cm})+$ without PPM; Nodal segment $(1.0 \mathrm{~cm})+8.6 \mu \mathrm{M}$ PPM; Nodal segment $(0.5 \mathrm{~cm})+$ without PPM; and, Nodal segment $(0.5 \mathrm{~cm})+8.6 \mu \mathrm{M}$ PPM. PPM ${ }^{\circledast}:$ Plant Preservative Mixture. 
Table 2. Multiplication rate (\%), number of shoots per explant, shoot length $(\mathrm{mm})$ and oxidation (\%) of $C$. odorata explants multiplied in vitro under different concentrations of 6-benzylaminopurine (BAP) added to doses of gibberellic acid (GA3).

\begin{tabular}{|c|c|c|c|c|c|c|}
\hline \multirow{2}{*}{$\begin{array}{l}\text { BAP } \\
(\mu \mathrm{M})\end{array}$} & \multicolumn{3}{|c|}{ Multiplication (\%) } & \multicolumn{3}{|c|}{ No. shoots } \\
\hline & $0.28 \mu \mathrm{M}$ GA3 & $1.12 \mu \mathrm{M} \mathrm{GA3}$ & Averages & $0.28 \mu \mathrm{M}$ GA3 & $1.12 \mu \mathrm{M}$ GA3 & Average: \\
\hline 2.2 & $64 \mathrm{bA}$ & $63 \mathrm{cA}$ & $63.5 c$ & $2.32 \mathrm{CB}$ & $3.00 \mathrm{bA}$ & $2.66 \mathrm{c}$ \\
\hline 3.3 & $76 \mathrm{abA}$ & $89 a b A$ & $82.5 b$ & $2.82 \mathrm{cB}$ & $3.41 \mathrm{abA}$ & $3.11 \mathrm{~b}$ \\
\hline 4.4 & $100 \mathrm{aA}$ & $100 \mathrm{aA}$ & $100 \mathrm{a}$ & $3.58 \mathrm{bA}$ & $3.68 \mathrm{aA}$ & $3.63 \mathrm{a}$ \\
\hline 6.6 & $63 \mathrm{bA}$ & 75 bcA & $69 b c$ & $3.49 \mathrm{bA}$ & $3.34 \mathrm{abA}$ & $3.41 \mathrm{a}$ \\
\hline 8.8 & $92 \mathrm{aA}$ & 70 bcB & $81 \mathrm{~b}$ & $4.16 \mathrm{aA}$ & $3.04 \mathrm{bB}$ & $3.60 \mathrm{a}$ \\
\hline \multirow[t]{3}{*}{ Averages } & $79 \mathrm{~A}$ & $79.4 \mathrm{~A}$ & & $3.34 \mathrm{~A}$ & $3.29 \mathrm{~A}$ & \\
\hline & \multicolumn{3}{|c|}{ Length $(\mathrm{mm})$} & \multicolumn{3}{|c|}{ Oxidation (\%) } \\
\hline & $0.28 \mu \mathrm{M}$ GA3 & $1.12 \mu \mathrm{M}$ GA3 & Averages & $0.28 \mu \mathrm{M} \mathrm{GA3}$ & $1.12 \mu \mathrm{M} \mathrm{GA} 3$ & Averages \\
\hline 2.2 & $1.88 \mathrm{aB}$ & $2.40 \mathrm{aA}$ & $2.14 a$ & $0.00 *$ & $0.00 *$ & $0.00 *$ \\
\hline 3.3 & $1.68 \mathrm{abA}$ & $1.32 \mathrm{bB}$ & $1.50 \mathrm{~b}$ & $0.00 *$ & $0.00 *$ & $0.00 *$ \\
\hline 4.4 & $1.19 \mathrm{bcA}$ & $1.38 \mathrm{bA}$ & $1.28 \mathrm{~b}$ & $0.00 *$ & $13.00 \mathrm{~b}$ & $0.00 *$ \\
\hline 6.6 & $1.18 \mathrm{cA}$ & $0.73 c B$ & $0.95 c$ & $0.00 *$ & $62.00 \mathrm{a}$ & $0.00 *$ \\
\hline 8.8 & $0.83 \mathrm{cA}$ & $0.83 \mathrm{cA}$ & $0.83 c$ & $0.00 *$ & $65.00 \mathrm{a}$ & $0.00 *$ \\
\hline Averages & $1.35 \mathrm{~A}$ & $1.33 \mathrm{~A}$ & & $0.00 *$ & $0.00 *$ & \\
\hline \multicolumn{2}{|c|}{ p-valor } & Multiplication & No. shoots & \multicolumn{2}{|c|}{ Length } & Oxidation \\
\hline \multirow{2}{*}{\multicolumn{2}{|c|}{$\begin{array}{l}\text { BAP } \\
\text { GA3 }\end{array}$}} & $<0.001$ & $<0.001$ & \multirow{2}{*}{\multicolumn{2}{|c|}{$<0.001$}} & 0.0071 \\
\hline & & 0.7411 & 0.5088 & & & - \\
\hline \multicolumn{2}{|c|}{$\mathrm{BAP} \times \mathrm{GA} 3$} & 0.0492 & $<0.001$ & \multicolumn{2}{|c|}{$\begin{array}{l}0.7614 \\
0.0016\end{array}$} & - \\
\hline \multicolumn{2}{|c|}{ CV. (\%) } & 22.50 & 18.85 & \multicolumn{2}{|c|}{27.97} & 66.28 \\
\hline
\end{tabular}

* Not evaluated due to the absence of oxidation. Averages followed by the same lower case letters in the columns and upper case letters in the rows are not significantly different by Tukey test $(p \geq 0.05)$. CV (\%): Coefficient of variation.

the other treatments $(p<0.001)$ (Table 2). In both GA3 doses, the increase in BAP concentration promoted a reduction in shoot length $(p<0.001)$.

BAP is a cytokinin-type growth regulator, inducer of cell division and widely used in the multiplication phase of $C$. odorata (Pérez et al., 2002; Valverde-Cerdas et al., 2008). In the in vitro multiplication phase, this growth regulator promotes the development of the aerial part and the number of shoots that capture nutrient reserves from the culture medium, causing a decrease in shoot size in in vitro plants (Almeida et al., 2020). The adequate concentration of GA3 combined with $\mathrm{BAP}$ in the in vitro multiplication phase of $C$. odorata interfered with the number of shoots per explant. This growth regulator is important in cell elongation and promoted the increase of Cordia trichotoma sprouts (Mantovani et al., 2001).

The results of the number of shoots obtained per explant were higher than those found in $C$. odorata multiplication by Pérez et al. (2002). These authors used seedling material and cultivated the species in culture medium supplemented with BAP, KIN and 2-iP, and found the best result (4.06 sprouts per explant) with $9.76 \mu \mathrm{M}$ of BAP. On the other hand, in Table 2, the result of our work (4.16 shoots per explant) were close to the best results observed by Peña-Ramírez et al. (2010) who achieved 4.6 shoots per explant by adding $20 \%$ coconut water in the TY17 culture medium and using hypocotyls. In contrast, Valverde-Cerdas et al. (2008) obtained 2.3 sprouts per explant using $3.1 \mu \mathrm{M}$ of BAP; while Rodriguez et al. (2003), found 2.5 shoots per explant after 45 days on medium with $2.2 \mu \mathrm{M}$ BAP.

In the media containing $0.28 \mu \mathrm{M} \mathrm{GA3}$ under different doses of BAP no oxidation of the explants was observed. The media with $1.12 \mu \mathrm{M} \mathrm{GA3}$ at the concentration of $4.4 \mu \mathrm{M}, 6.6 \mu \mathrm{M}$ and $8.8 \mu \mathrm{M}$ of BAP showed 13,62 , and $65 \%$ oxidized explants, respectively (Table 2). The oxidation observed can be attributed to regulator levels or phenolic oxidation. High concentrations of growth regulators can cause intoxication and oxidation of explants, indicative of inadequate concentrations (Almeida et al., 2020), as well as modify or inhibit explant growth (Lima et al., 2020). The browning resulting from phenol oxidation is due to polyphenol oxidase activity, which results in the production of quinones, which are melanic compounds that contribute to browning and death of explants (Huh et al., 2017).
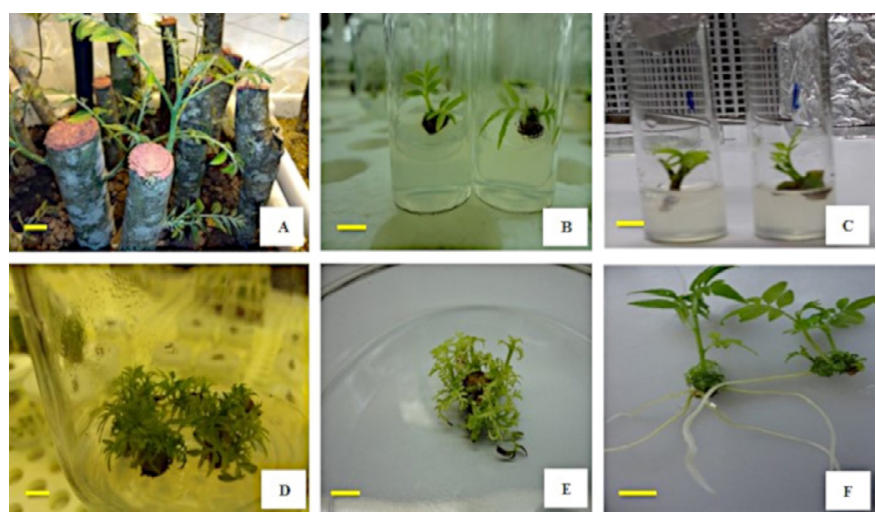

Figure 1. In vitro regeneration of C. odorata. A) Budding cuttings; B) Establishment of $0.5 \mathrm{~cm}$ nodal segments; C) Establishment of $1.0 \mathrm{~cm}$ nodal segments; D) Multiplication, explants supplemented with $0.28 \mu \mathrm{M} \mathrm{GA3}$ and $8.8 \mu \mathrm{M}$ BAP; E) Explant with sprouts; and; F) Rooting of explants with 4.90 $\mu \mathrm{M}$ AIB. $($ Bar $=1 \mathrm{~cm})$.

\section{Root induction and acclimatization}

In the rooting induction phase, callogenesis was observed in explants grown on medium with the auxins AIB and ANA (Figure 1). Callogenesis in some forest species precedes rooting 
(Navroski et al., 2015). Plants have the ability to regenerate their tissues, this can occur by cell dedifferentiation, which under the action of phytohormones generates a mass of cell proliferation, called callus (Fehér, 2019).

The first adventitious roots of $C$. odorata sprouts appeared in the culture medium containing AIB after 15 days from the start of rooting induction. The culture medium plus $4.90 \mu \mathrm{M}$ of AIB showed rooting rate of $60 \%$ of explants and root length with $2.76 \mathrm{~cm}$, being different from the medium containing $5.37 \mu \mathrm{M}$ of ANA, treatment that reached $26 \%$ rooting. Explants maintained on medium with $5.70 \mu \mathrm{M}$ EIA and control did not show rooting in the experiment (Table 3 ). In the ex vitro acclimatization, the seedlings that formed roots had a survival percentage of $97 \%$, while in the sprouts without roots the survival was only $24 \%$, demonstrating the need for rooting phase in the formation of seedlings and success in obtaining micropropagated and acclimatized seedlings (Table 4).

The use of AIB is indicated in the in vitro rooting of $C$. odorata, as proven by Rodríguez et al. (2003), who using MS culture medium plus $4.4 \mu \mathrm{M}$ AIB, obtained 4.18 roots per explant with $3.9 \mathrm{~cm}$ in length. Valverde-Cerdas et al. (2008), using $9.8 \mu \mathrm{M}$ of AIB obtained 6.5 roots per explant. The work of García-Gonzáles et al. (2011) demonstrated that using MS culture medium supplemented with $8.8 \mu \mathrm{M}$ of BAP and 16.1 $\mu \mathrm{M}$ of NAA obtained the formation of 3.9 roots per plant after six weeks.

The low number and length of $C$. odorata roots found in our study, compared to other studies, may be related to the evaluation time and the residual effect of GA3 and BAP from the multiplication phase. Using MS culture medium, with activated charcoal and combinations of $2.2 \mu \mathrm{M}$ of BAP and 2.68 $\mu \mathrm{M}$ of NAA, Huamán et al. (2012) obtained, after five weeks of $C$. odorata culture, $100 \%$ rooting, 8.13 roots per explant and $10.43 \mathrm{~cm}$ in length. Activated carbon can be used in the composition of the rooting medium, for its capacity to absorb inhibiting and toxic residual substances from the previous

Table 3. Rooting rate (\%), number of roots and root length $(\mathrm{cm})$ of $C$. odorata under different auxin concentrations.

\begin{tabular}{cccc}
\hline Treatment & $\begin{array}{c}\text { Rooting rate } \\
(\%)\end{array}$ & $\begin{array}{c}\text { Numbe } \\
\text { of roots }\end{array}$ & $\begin{array}{c}\text { Root length } \\
\text { (cm) }\end{array}$ \\
\hline $4.90 \mu \mathrm{M}$ AlB & $60.00 \mathrm{a}$ & $2.63^{\mathrm{ns}}$ & $2.76 \mathrm{a}$ \\
$5.37 \mu \mathrm{M}$ ANA & $26.00 \mathrm{~b}$ & 2.27 & $1.12 \mathrm{~b}$ \\
$5.70 \mu \mathrm{M}$ AIA & $0.00^{*}$ & $0.00^{*}$ & $0.00^{*}$ \\
Control & $0.00^{*}$ & $0.00^{*}$ & $0.00^{*}$ \\
CV (\%) & 14.00 & 31.54 & 24.70 \\
\hline
\end{tabular}

* Not evaluated due to lack of rooting. Means followed by the same letter in the column do not differ significantly by Tukey test $(p<0.05)$. ns: Treatments were not significantly different by Tukey test $(p \leq 0.05)$. CV (\%): Coefficient of variation.

Table 4. Survival (\%) of acclimatized explants with and without C. odorata root.

\begin{tabular}{cc}
\hline Treatment & Survival (\%) \\
\hline With root & $97 \mathrm{a}$ \\
Without root & $24 \mathrm{~b}$ \\
p-valor & 0.00203 \\
\hline
\end{tabular}

Averages followed by the same letter do not differ significantly from each other by the F test $(p \geq 0.05)$. phase of micropropagation, promoting better rooting rates (Lima et al., 2020).

The interaction between the concentrations of growth regulators BAP and GA3 may serve as an indication for future evaluation of new protocols for micropropagation of $C$. odorata, considering the genetic diversity and the importance of the species, and thus may contribute to increase the rate of multiplication and rooting of explants, as well as the rescue and production of seedlings from selected matrices.

\section{Conclusions}

The use of explants from nodal segments formed from cuttings taken from crown branches used in micropropagation is feasible in the vegetative rescue of adult $C$. odorata trees, enabling the selection and multiplication of superior genotypes.

The use of nodal segments $1 \mathrm{~cm}$ long presents a higher percentage of in vitro regeneration.

Association of $8.8 \mu \mathrm{M}$ of $\mathrm{BAP}$ and $0.28 \mu \mathrm{M}$ of $\mathrm{GA} 3$ in culture medium with MS promoted production of 4.16 shoots per explant after 30 days of culture.

The explants maintained in medium with the addition of $4.9 \mu \mathrm{M}$ AIB showed $60 \%$ rooting. The rooted and acclimatized seedlings showed $97 \%$ survival.

\section{Acknowledgments}

Research supported by the Fundação de Amparo à Pesquisa e Inovação de Santa Catarina - FAPESC (Rede Guarani Serra Geral, agree. FAPESC2015TR1067) and Conselho Nacional de Desenvolvimento Científico e Tecnológico - CNPq (Project 441396/2017-8, MCTI/CNPq N. 20/2017 - Nexus II) and research grant (processes no. 307376/2017-6 and 305376/2018-7). To the Programa de Bolsas de Monitoria de Pós-Graduação - PROMOP/UDESC for granting the scholarship.

\section{Compliance with Ethical Standards}

Author contributions: Conceptualization: CFSJ, MDC, TDR, PB, MICB; Data curation: CFSJ, MDC, TDR; Formal analysis: CFSJ, MDC; Funding acquisition: MDC, TDR, PB, MICB; Investigation: CFSJ, MDC, TDR; Methodology: CFSJ, MDC, TDR; Formal analysis: CFSJ, MDC; Project administration: CFSJ, MDC, TDR, PB, MICB; Resources: MDC, TDR, PB, MICB; Supervision: CFSJ, MDC, TDR; Validation: CFSJ, MDC, TDR, PB, MICB; Visualization: CFSJ, MDC, TDR, PB, MICB; Writing review \& editing: CFSJ, MDC, TDR, PB, MICB.

Conflict of interest: The authors declared that there is no possible conflict of interest (professional or financial) that may influence the article.

Financing source: This research was supported by FAPESC (Rede Guarani Serra Geral, conv. FAPESC2015TR1067) and MCTI/CNPq № 20/2017 Nexus II - CNPq 441396/2017-8. 


\section{Literature Cited}

Almeida, L. V. S.; Oliveira, V. J. S. O.; Jacobi, C. C. B., Almeida, W. A. B., Carvalho, M. J. S. Vernonia condensata Baker: an alternative for large-scale seedling production. Ciência Rural, v.50, n.3, e20180941, 2020. https://doi.org/10.1590/01038478 cr20180941.

Alvim, B. F. M., Souza, A. V. V.; Lima-Brito, A.; Fonseca, P. T.; Soares, T. L.; Santana, J. R. F. (2020). In vitro conservation of Amburana cearensis (Fabaceae). Ciência Rural, v. 50, n.7, e20190729, 2020. https://doi.org/10.1590/0103-8478cr20190729.

Bidabadi, S. S.; Jain, S. M. Cellular, molecular, and physiological aspects of in vitro plant regeneration. Plants v.9, n.6, e702, 2020. https://doi.org/10.3390/plants9060702.

Brasil. Ministério do Meio Ambiente. Portaria no 444, de 17 de dezembro de 2014. Reconhece como espécies da fauna brasileira ameaçadas de extinção aquelas constantes da "Lista Nacional Oficial de Espécies da Fauna Ameaçadas de Extinção" - Lista, conforme Anexo I da presente Portaria. Diário Oficial da União, v.151, n.245, seção 1, p.121-126, 2014. https://www.icmbio. gov.br/cepsul/images/stories/legislacao/Portaria/2014/p_ mma_444_2014_lista_esp\%C3\%A9cies_ame\%C3\%A7adas_ extin\%C3\%A7\%C3\%A3o.pdf. 17 Feb. 2020.

Cançado, G. M.; Braga, F. T.; Souza, R. A. V.; Nunes, C.F.; Ribeiro, A. P.; Soares, B. D. F. Cultivo in vitro da oliveira e suas aplicações. In: Oliveira, A. F. (Ed.). Oliveira no Brasil: tecnologias de produção. Belo Horizonte: Epamig, 2013. p. 275-310.

Castro, M. T; Montalvão, S. C. L; Monnerat, R. G. Breeding and biology of Hypsipyla grandella Zeller (Lepidoptera: Pyralidae) fed with mahogany seeds (Swietenia macrophylla King). Revista Journal of Asia-Pacific Entomology, v.19, n.1, p. 217-221, 2016. https://doi. org/10.1016/j.aspen.2016.01.008.

Cervi, A. C.; Linsingen, L. V.; Patrício, P. E. O gênero Cedrela P. Browne (Meliaceae) no sul do Brasil. Acta Biológica Paranaense, v. 37, n.12, p.105-110, 2008. https://doi.org/10.5380/abpr.v37i0.13198.

Fehér, A. Callus, dedifferentiation, totipotency, somatic embryogenesis: what these terms mean in the era of molecular plant biology? Frontiers in Plant Science, v.10, e00536, 2019. https://doi.org/10.3389/fpls.2019.00536.

García-Gonzáles, R.; Delgado, M.; González, Y.; González, A.; Garriga, M.; Caligari, P. D. S.; Carrasco, B.; Quiroz, K. in vitro propagation of cedar (Cedrela odorata L.) from juvenile shoots. Chilean Journal of Agricultural Research, v.71, n.3, p. 376-382, 2011. https://doi. org/10.4067/S0718-58392011000300005.

Huamán, X.; Ruiz-Sánchez, M. E.; Guerrero-Abad, J. C.; Pichis-García, R.; García, L.; Solis, R. Propagación in vitro de segmentos nodales de cedro (Cedrela odorata L.) obtenidos a partir de semillas botanicas. Folia Amazónica, v. 21, n.1-2, p. 109-114, 2012. https://doi.org/10.24841/fa.v21i1-2.39.

Huh, Y. S.; Lee, J. K.; Nam, S. Y. Effect of plant growth regulators and antioxidants on in vitro plant regeneration and callus induction from leaf explants of purple passion fruit (Passiflora edulis Sims). Journal of Plant Biotechnology, v. 44, n. 3, p. 335-342, 2017. https://doi.org/10.5010/JPB.2017.44.3.335.
Lesher-Gordillo, J. M.; Martinez-Sanchez, J.L.; Orduna-Rodas, P.; Hernandez-Carreta, A. I. Genetic diversity of the red cedar (Cedrela odorata) in the state of Tabasco, México. Bosque, v.39, n.3, p. 411-417, 2018. https://doi.org/10.4067/S071792002018000300411.

Lima, A. P. P. S.; Brito, A. L.; Santana, J. R. F. Micropropagation of Chapada Diamantina ornamental bromeliad. Ciência Rural, v.50, n.2, e20180922, 2020. https://doi.org/10.1590/01038478 cr20180922.

Mantovani, N. C.; Franco, E. T. H.; Vestena, S. Regeneração in vitro de Louro-pardo (Cordia trichotoma (Vellozo) Arrabida ex Steudel). Ciência Florestal, v.11, n.2, p. 93-101, 2001. https://doi. org/10.5902/198050981658.

Martins, K.; Ribas, L. A.; Moreno, M. A.; Wadt, L. H. O. Consequências genéticas da regeneração natural de espécies arbóreas em área antrópica, AC, Brasil. Acta Botanica Brasilica, v.22, n.3, p.897-904, 2008. https://doi.org/10.1590/S0102-33062008000300025.

Moura, L.C.; Titon, M.; Fernandes, J.S.C.; Santana, R.C.; Oliveira, M.L.R. Micropropagação de sucupira-preta por meio de gemas axilares. Pesquisa Agropecuária Brasileira, v.47, n.12, p. 1691-1698, 2012. https://doi.org/10.1590/S0100-204X2012001200003.

Mroginski, L. A.; Rey, H. Y. Micropropagation of Paradise Tree (Melia azedarach) by in vitro culture of axillary buds. In: Lambardi, M., Ozudogru, E., Jain, S. (Eds.). Protocols for micropropagation of selected economically-important horticultural plants. Totowa: Humana Press, 2012. p.223-230. (Methods in molecular biology (methods and protocols), 994). https://doi.org/10.1007/978-162703-074-8_17.

Murashige, T.; Skoog, F. A revised medium for rapid growth and bioassays with tobacco tissue cultures. Physiologia Plantarum, v.15, n.3, p. 473-497, 1962. https://doi. org/10.1111/j.1399-3054.1962.tb08052.x.

Navroski, M. C.; Pereira, M. O.; Hess, A. F.; Silvestre, R.; Ângelo, A. C.; Fazzini, A. J.; Alvarenga, A. A. Resgate e propagação vegetativa de Sequoia sempervirens. Floresta, v. 45, n.2, p. 383-392, 2015. http://dx.doi.org/10.5380/rf.v45i2.35407.

Oliveira, L. S.; Dias, P. C.; Brondani, G. E. Micropropagação de espécies florestais brasileiras. Pesquisa Florestal Brasileira, v. 33, n. 76, p. 439-453, 2013. https://doi.org/10.4336/2013.pfb.33.76.481.

Peña-Ramírez, Y. J.; García-Sheseña, I.; Hernández-Espinoza, Á.; Domínguez-Hernández, A.; Barredo-Pool, F. A., GonzálezRodríguez, J. A.; Robert, M. L. Induction of somatic embryogenesis and plant regeneration in the tropical timber tree Spanish red cedar [Cedrela odorata L. (Meliaceae)]. Plant Cell Tiss Organ Cult, v. 105, p. 203-209, 2011. https://doi.org/10.1007/s11240-0109853-y.

Peña-Ramírez, Y. J.; Juárez-Gómez, J.; Gómez-Lópes, L.; JerónimoPérez, J. L.; García-Sheseña, I.; González-Rodríguez, J. A.; Robert, M. L. Multiple adventitious shoot formation in Spanish Red Cedar (Cedrela odorata L.) cultured in vitro using juvenile and mature tissues: an improved micropropagation protocol for a highly valuable tropical tree species. In Vitro Cellular \& Developmental Biology - Plant, v. 46, n. 2, p. 49-160, 2010. https://doi. org/10.1007/s11627-010-9280-0. 
Pérez, J.; Mesén, F.; Aguilar, M.; Hilje, L. Desarrollo de un método de micropropagación aplicable a genotipos selectos de Cedrela odorata L. Optimización de la fase de multiplicación. Revista Forestal Centroamericana, v.11, n.38, p. 67-71, 2002. http://hdl. handle.net/11554/10394. 17 Feb. 2020.

R Core Team. R: A language and environment for statistical computing. Vienna: R Foundation for Statistical Computing, 2018. https:// www.R-project.org. 10 Jan. 2021.

Robert, M. L.; Juárez-Gómez, J.; Chaires-Pacheco, M.; Peña-Ramírez, Y. J. Successive grafting confers juvenility traits to adult Spanish red cedar (Cedrela odorata Linnaeus): a tool for the rescue of selected materials. New Forests, v.51, p.335-347, 2020. https:// doi.org/10.1007/s11056-019-09736-7.

Rodríguez, R.; Daquinta, M.; Capota, I.; Pina, D.; Lezcano, Y.; GonzálezOlmedo, J. L. Nuevos aportes a la micropropagación de Swietenia macrophylla $\times$ Swietenia mahogani (Caoba hibrida) y Cedrela odorata (Cedro). Cultivos Tropicales, v. 24, n.3, p. 23-27, 2003. Dec. 7, 2019. https://doi.org/10.24841/fa.v22i1-2.45.
Salles, E. A. P. B.; Alcantara, G. B.; Quoirin, M. G. G.; Gonçalves, A. N.; Higa, A. R. Desinfestação e introdução in vitro de segmentos nodais de Acacia mearnsii. Pesquisa Florestal Brasileira, v. 37, n. 92, p. 485-491, 2017. https://doi.org/10.4336/2017.pfb.37.92.1392.

Silveira, S. S.; Cordeiro-Silva, R.; Degenhardt-Goldbach, J.; Quoirin, M. Micropropagation of Calophyllum brasiliense (Cambess.) from nodal segments. Brazilian Journal of Biology, v.76, n.3, p. 656663, 2016. https://doi.org/10.1590/1519-6984.23714.

Stuepp, C. A.; Wendling, I.; Xavier, A.; Zuffellato-Ribas, K. C. Vegetative propagation and application of clonal forestry in Brazilian native tree species. Pesquisa Agropecuária Brasileira, v.53, n.9, p.985-1002, 2018. https://doi.org/10.1590/s0100$204 \times 2018000900002$.

Valverde-Cerdas, L.; Rojas-Vargas, A.; Hine-Gómez, A. In vitro propagation of Albizia guachapele, Cedrela odorata, Platymiscium pinnatum and Guaiacum sanctum. Plant Tissue Culture and Biotechnology, v. 18, n. 2, p. 151-156, 2008. https:// doi.org/10.3329/ptcb.v18i2.3397. 